\title{
Emergy evaluation and Life Cycle Assessment of a second generation bioethanol production
}

\author{
N. Patrizi, F. Morandi \& F. M. Pulselli \\ Ecodynamics group, Department of Earth, Environmental and \\ Physical Sciences, University of Siena, Italy
}

\begin{abstract}
Bioethanol is obtained from various raw biomasses and by means of optimized process technologies. It can be a substitute for gasoline, which implies greenhouse gas (GHG) emission reduction. The type of feedstock determines the classification of bioethanol: first generation (starch-based biomass or simple sugar-based feedstock) and second generation (lignocellulosic material as straw and wood). Second generation bioethanol production requires cellulosic biomass, which overcome the problems of first generation like food competition and low efficacy in GHG emission reduction. Sustainability evaluations of (first and second generation) bioethanol production have been proposed in the past by means of systemic indicators like emergy analysis and Life Cycle Assessment (LCA). A joint use of emergy and LCA of a possible implementation of a second generation bioethanol production chain is presented in this study. The emergy methodology has been used to test the physical consistency of the investment required to implement the production process, as well as the benefit of the biofuel-gasoline substitution. The effect of this substitution has been also evaluated by including the LCA of this production chain within the GHG balance of the Province of Siena. Keywords: biofuels, biorefinery, second generation bioethanol, geothermal heat, straw, greenhouse gas emissions (GHG), Life Cycle Assessment (LCA), emergy investment.
\end{abstract}

\section{Introduction}

Bioethanol is the renewable substitute of gasoline. It can be obtained from various raw biomasses, by means of optimized process technologies. The type of feedstock determines the classification of bioethanol: first generation $(1 \mathrm{G}-$ starch-based 
biomass or simple sugar-based feedstock) and second generation (2Glignocellulosic material as straw and wood) [1]. First generation bioethanol has generated concerns about its effective capacity in reducing GHG emission and its competition with food production $[2,3]$. The large availability of raw feedstock, small GHG emissions in the overall production process and no food competition stimulate a growing interest on second generation bioethanol production [4]. Compared to conventional fuels, lignocellulosic bioethanol production has high costs, even though in the last years a number of solutions have been proposed $[5,6]$. The ideas of biorefinery and bio-based economy have been introduced to reduce costs of bioethanol production by virtue of the joint production of food, energy and chemicals and the integration of production processes [7-10]. A biorefinery is defined as: "the sustainable processing of biomass into a spectrum of marketable products (food, feed, materials, and chemicals) and energy (fuels, power, heat)" [11]. The bio-based economy takes inspiration from the Industrial Symbiosis concept and forecasts the integration of industrial plants and agricultural ecosystems $[8,12]$. This integration implies that the output of the agricultural production can be the input for other plant leading to environmental and economic benefits thanks to a more efficacious use of resources [13]. The European Union policy had the promotion of biofuels as one of its core policy mandates in the energy and climate change area. Following the EU objectives, in 2003 the European Commission started to emanate directives and official communication regarding the promotion of biofuels in the transport sector [14-17]. To reach these objectives, each Nation should increase its biofuel production and decrease its $\mathrm{CO}_{2}$ emissions.

In this study, we hypothesize the implementation of a second generation bioethanol production chain within the Province of Siena (Tuscany, Italy), fed by local residues, namely biomass from agro-productions and heat from geothermal electricity production. Here we update the results of two previous experiments based on Emergy evaluation and Life Cycle Analysis of the same system, [18, 19] and investigate the contribution that derives from the joint use of these holistic methodologies. These methods have been used to account for the exploitation of natural resources and generation of potential impacts. The LCA is a useful tool for assessing the environmental performances and impacts of production processes $[2,20]$. The emergy analysis is a thermodynamics-based metric that contributes to identify and measure all the inputs (energy and matter) to the system, expressed in a common unit, namely, the equivalent solar energy.

In this paper, the LCA is applied to measure the environmental effects of the substitution of bioethanol for the $10 \%$ of gasoline used in the Province of Siena; the emergy analysis is used to quantify the environmental investment necessary for operationalizing this substitution; moreover, the benefit of the avoided consumption of gasoline is evaluated in emergy terms. The joint lecture of these results can represent a first step of an environmental feasibility analysis of the bioethanol production process. 


\section{Materials and methods}

\subsection{Case study description}

In the Province of Siena (Italy), 37\% of the total area is devoted to agriculture and the main crop productions are wheat, oat and barley. Therefore, a great potential availability of crop residues can be used as feedstock for second generation bioethanol production. Moreover this territory has another peculiarity: geothermal heat that is used for electricity production, which supply about the $98 \%$ of the electricity consumed in the provincial area. Along the electricity production process a steam flow is generated that is usually re-injected into geothermal reservoir. In this case study we have hypothesized the joint use of these two residual flows (straw and steam) as input for the implementation of a second generation bioethanol production chain, taking inspiration by the Danish IBUS (Integrated Biomass Utilization System) [22]. We have hypothesized a biorefinery coupled with a geothermal-electricity production plant feed by residual straw. The bioethanol production plant must be located in the northwestern part of the Province of Siena, where the majority of geothermal wells are located. In compliance with the Italian law (D.Lgs 296/2010) for the sustainable use of biomass for energy generation, the straw should be collected in the nineteen municipalities located within $70 \mathrm{~km}$ from plant's location. A detailed description of the entire bioethanol production chain can be found in Patrizi et al. [18]. In 2011 about 43,000 tons of gasoline were consumed within the territory of the Province of Siena [23]. To substitute $10 \%$ of that gasoline, about 7,000 tons of bioethanol are required (using a Lower Heating Value for gasoline equal to $44 \mathrm{MJ} / \mathrm{kg}$ and $28.8 \mathrm{MJ} / \mathrm{kg}$ for bioethanol [24]). The yield ethanol/straw obtained in the Danish plant is $223 \mathrm{~kg}$ ethanol per ton of straw [25], therefore about 31,600 ton of straw are required to produce the forecasted tons of bioethanol. Data on straw production have been calculated from data on local crop extension [26], local crop yields [27] and the species related ratio straw grains [28]. In the selected municipalities in the period 2006-2010 about 58,400 tons of straw from oat, barley and wheat have been produced (it approximately corresponds to the $55 \%$ of the total straw production of these 19 municipalities, and the $28 \%$ of the total straw production within the entire Province of Siena). That amount of straw does not affect the soil quality [29, 30] and may preserve the current use of straw for other purposes (mainly in the livestock sector).

\subsection{Emergy analysis}

Emergy is a thermodynamic metric that estimates the environmental cost of something in terms of the energy that drives (directly and indirectly) all the processes on the biosphere. Emergy of a product depends on the way which it is produced and is defined as the solar energy directly and indirectly necessary to make a service or a product [31]. By means of a conversion factor called Unit Emergy Value (UEV that is the emergy per unit energy) different types of energy 
flows, energy embodied in materials and services required to produce a product are converted in a common unit of solar equivalent Joules (semj). UEVs are expressed in semj/J and semj/g respectively. The total emergy of a system is given by the sum of all emergy inputs to the system, that is the energy (or mass) content of all inputs multiplied by their corresponding UEV.

Figure 1 is the representation through the Energy System Language [31] of the hypothesized bioethanol production system.

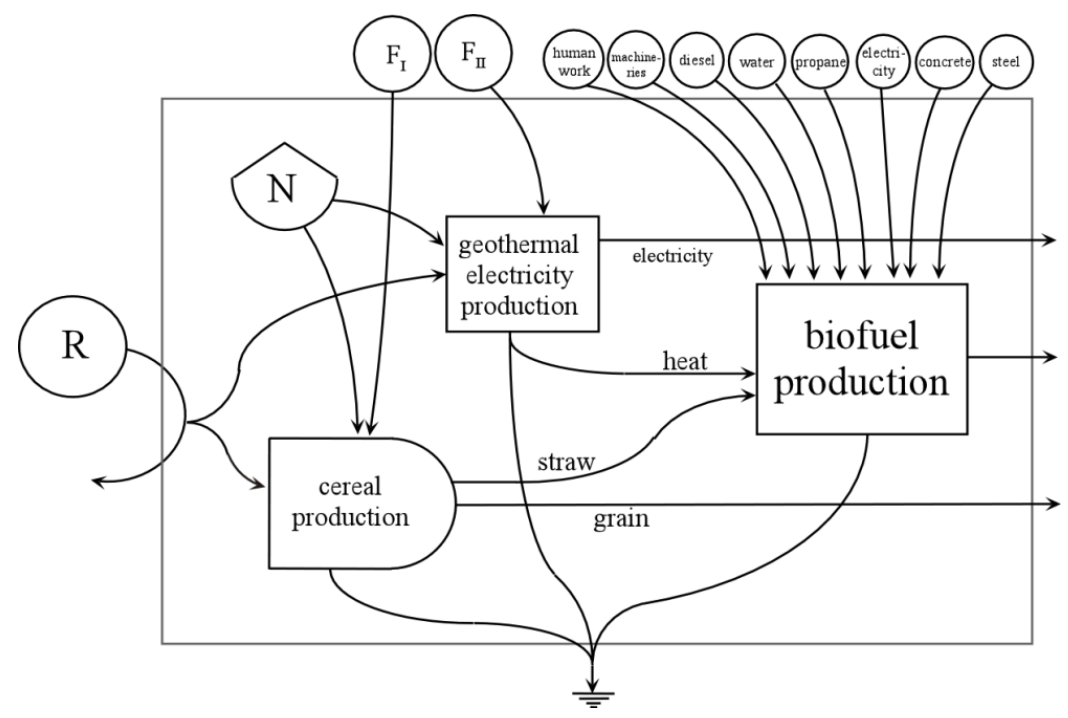

Figure 1: Energy diagram of the hypothesized bioethanol production system.

In Figure 1 circles represent inputs and arrows indicate the material and energy flows that converge to the production processes, namely cereal, geothermal electricity and biofuel.

The emergy investment needed for the bioethanol production has been also identified. It is defined as the quantity of inputs, expressed in emergy terms, that must be added to an existing systems or processes (in our case cereal and electricity production), in order to obtain further output(s) or optimize the use of resources [19].The detailed inputs (as human work, water, etc.) indicated in Figure 1 , that directly feed the production of biofuel (from straw and heat collection to bioethanol production), have been inventoried, as reported in Table 1, and translated into emergy by means of suitable UEVs.

\subsection{Life Cycle Assessment}

The Life Cycle Assessment (LCA) is an internationally recognized methodology for the evaluation of the environmental performances of a product along its entire production chain, from "cradle to grave" [32]. In this study the potential impacts 
derived from the hypothesized bioethanol production chain have been evaluated from the straw production to the bioethanol production. Therefore this LCA is from cradle to gate as it would be not possible to define how the bioethanol would be distributed across the Province of Siena. In this analysis only the contribution to climate change has been taken into consideration, because our main aim was to test the effect of the replacement of the $10 \%$ of gasoline with locally produced bioethanol in the GHG balance of the Province of Siena.

The functional unit (FU) of the study is 1 ton of bioethanol produced.

The LCA software tool SimaPro 7.3.3 (www.pre.nl) has been used for the Life Cycle Inventory modeling and Life Cycle Impact Assessment. From the LCA perspective the bioethanol production chain has been divided into 4 steps. Step 1 takes into accounts input flows required for the straw production and harvesting. Step 2 concerns the transports required to carry the straw from each municipality to the biorefinery. Step 3 accounts for all the input flows to processes that would take place inside the biorefinery. Step 4 would represents the final distribution of bioethanol (it is worth to point out that this last step is outside the boundaries of the analysis and therefore potential impacts have not been evaluated). Data in Table 1 are referred to the total bioethanol production process (7,060 tons): they have been allocated to the functional unit and used as input for the LCA (Table 2).

\section{Results and discussion}

Table 1 reports the calculation of the emergy investment for the bioethanol production system in the Province of Siena: production phases, the amount of resources used, their UEV and associated emergy flow are reported for each input. The sum of the emergy of the inputs gives the emergy investment for implementing the production process (last column), that is referred to the process output - i.e. the quantity of bioethanol needed to replace $10 \%$ of gasoline consumption in the Provincial area, that is 7,060 t. The investment per unit product (UEI - unit emergy investment) for the bioethanol production is calculated by dividing the total emergy investment by the quantity of product (expressed in gram) and reported in the last line of Table 1. As reference point, the global baseline of $9.26 \times 10^{24} \mathrm{semj} / \mathrm{yr}$ has been considered [33]; the reference year is 2011.

The total emergy investment needed for the implementation of this integrated agro-industrial system can be compared with the emergy value of the energy saved by substituting bioethanol for the $10 \%$ of gasoline consumption in the Province of Siena. The avoided use of 4,300 t of gasoline corresponds to $1.27 \mathrm{E}+19 \mathrm{semj} / \mathrm{yr}$ in emergy terms. This is the benefit of the project, that doubles the total emergy investment (7,060 t of bioethanol correspond to $6.24 \mathrm{E}+18 \mathrm{semj} / \mathrm{yr})$.

Since bioethanol utilization results in a reduction of gasoline consumption we can compare the UEI of bioethanol with the UEV of gasoline. Comparing the UEI of bioethanol produced in the hypothesized refinery and the UEV of gasoline, we can see that the former is $8.84 \mathrm{E}+08 \mathrm{semj} / \mathrm{g}$, more than three times lower than the latter $(2.95 \mathrm{E}+09 \mathrm{semj} / \mathrm{g}$; [34]). 
Table 1: Emergy investment calculation and unit emergy investment for the hypothesized bioethanol production in the Province of Siena.

\begin{tabular}{|c|c|c|c|c|c|c|}
\hline ITEM & DETAIL & $\begin{array}{l}\text { INPUT * } \\
\text { Unit } \mathrm{yr}^{-1}\end{array}$ & Unit & $\begin{array}{c}\text { UEV } \\
\left(\text { (semj unit }^{-1}\right) \\
\text { baseline } \\
9.26 \mathrm{E}+24 \\
\end{array}$ & REFERENCE & 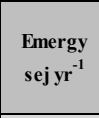 \\
\hline \multicolumn{7}{|l|}{ POST AGRICULTURAL PHASE } \\
\hline machineries for straw collection & diesel $^{\mathrm{a}}$ & $7.12 \mathrm{E}+08$ & $\mathrm{~g}$ & $2.86 \mathrm{E}+09$ & [36] & $2.04 \mathrm{E}+18$ \\
\hline machineries for straw collection & steel $^{\mathrm{a}}$ & $2.01 \mathrm{E}+08$ & $\mathrm{~g}$ & $3.38 \mathrm{E}+09$ & [37] & $6.80 \mathrm{E}+17$ \\
\hline human work for straw collection & human work ${ }^{\mathrm{a}}$ & $9.21 \mathrm{E}+08$ & $\mathrm{~J}$ & $4.41 \mathrm{E}+06$ & [38] & $4.06 \mathrm{E}+15$ \\
\hline \multicolumn{7}{|l|}{ TRANSPORT OF STRAW TO THE BIOREFINERY } \\
\hline light transport & trakker $^{\mathrm{b}}$ & $1.72 \mathrm{E}+12$ & gkm & $5.38 \mathrm{E}+04$ & [39] & $9.23 \mathrm{E}+16$ \\
\hline \multicolumn{7}{|l|}{ INDUSTRIAL PHASE } \\
\hline water & water $^{\mathrm{c}}$ & $6.20 \mathrm{E}+08$ & $\mathrm{~g}$ & $1.84 \mathrm{E}+06$ & [40] & $1.14 \mathrm{E}+15$ \\
\hline plant & concrete $^{\mathrm{d}}$ & $1.42 \mathrm{E}+08$ & $\mathrm{~g}$ & $1.78 \mathrm{E}+09$ & {$[38]$} & $2.53 \mathrm{E}+17$ \\
\hline plant & Reinforcing steel $^{\mathrm{d}}$ & $8.00 \mathrm{E}+07$ & $\mathrm{~g}$ & $3.38 \mathrm{E}+09$ & [37] & $2.71 \mathrm{E}+17$ \\
\hline \multirow[t]{3}{*}{ energy } & Electricity $^{\mathrm{c}}$ & $2.16 \mathrm{E}+13$ & $\mathrm{~J}$ & $1.35 \mathrm{E}+05$ & [41] & $2.90 \mathrm{E}+18$ \\
\hline & Process steam (geoth) & $1.25 \mathrm{E}+14$ & $\mathrm{~J}$ & $0.00 \mathrm{E}+00$ & {$[42]$} & $0.00 \mathrm{E}+00$ \\
\hline & propane $^{\mathrm{c}}$ & $3.42 \mathrm{E}+10$ & $\mathrm{~J}$ & $6.65 \mathrm{E}+04$ & [36] & $2.27 \mathrm{E}+15$ \\
\hline \multirow[t]{2}{*}{ TOTAL EMERGY INVESTMENT } & & & & & & $6.24 \mathrm{E}+18$ \\
\hline & & & & UEI** semj/g & & \\
\hline \multicolumn{2}{|c|}{\begin{tabular}{l|l|} 
output & bioethanol produced \\
\end{tabular}} & $7.06 \mathrm{E}+09$ & $\mathrm{~g}$ & $8.84 \mathrm{E}+08$ & & \\
\hline $\begin{array}{l}\text { * inputs refer to } 7,060 \mathrm{t} \text { of bioethanol produced } \\
* * \text { UEI= Unit Emergy Investment for bioethano } \\
\text { a [9] - b [our elaboration] - c [34] - d [35] }\end{array}$ & $\begin{array}{l}\text { d by the hypothesized bi } \\
\text { l production }\end{array}$ & orefinery in & the $\operatorname{Pr}$ & ovince of Siena & & \\
\hline
\end{tabular}

The total emergy investment is $6.24 \mathrm{E}+18 \mathrm{semj} / \mathrm{yr}: 2.72 \mathrm{E}+18 \mathrm{semj} / \mathrm{yr}$ for straw collection, $9.23 \mathrm{E}+16 \mathrm{semj} / \mathrm{yr}$ for transportation and $3.43 \mathrm{E}+18 \mathrm{semj}$ for the industrial phase. The UEI for bioethanol is $8.84 \mathrm{E}+08 \mathrm{semj} / \mathrm{g}$. The higher emergy investment derives from the industrial phase $(55 \%)$ therefore the post agricultural phase requires a relatively low emergy $(43 \%)$ and the transportation phase can be considered negligible as requires only the $2 \%$ of the whole evaluated emergy investment. In particular, 33\% of the total environmental investment for the bioethanol production process is represented by diesel for the post agricultural phase and $47 \%$ by the electricity for the industrial phase.

The availability of residual resources has been evaluated as well as the benefit from the emergy and energy point of view. To complete the environmental feasibility an LCA of the whole production chain has been carried out. The main aim of this analysis has been the evaluation of the consequences in the GHG balance of the Province of Siena due to the substitution of $10 \%$ of gasoline with the "locally produced" bioethanol.

According to the LCA methodology, the input flows for the total production process (Table 1) have been inventoried and allocated to the UF of the analysis (1 ton of bioethanol) and reported in Table 2 .

By means of the specific LCA software the total amount of $\mathrm{CO}_{2}$ eq per tons of bioethanol has been calculated. Figure 2 reports the amount of $\mathrm{CO}_{2}$ eq due to the production of 1 ton of bioethanol.

4,246 tons of $\mathrm{CO}_{2}$ eq are the emissions associated with the production of 7,060 tons of bioethanol; the total $\mathrm{CO}_{2}$ eq released per ton of bioethanol is $601.51 \mathrm{~kg}$. 
Table 2: Inventory of input flows required for the production of 1 ton of bioethanol by means of the hypothesized system.

\begin{tabular}{|c|c|c|c|c|}
\hline & & SUBSTANCES & AMOUNT & UNIT \\
\hline \multirow{9}{*}{ INPUT } & \multirow{2}{*}{ Raw materials } & Straw $^{\mathrm{a}}$ & 4484.30 & $\mathrm{~kg}$ \\
\hline & & Additives and enzymes ${ }^{\mathrm{b}}$ & & \\
\hline & Water & Water $^{\mathrm{c}}$ & 87.89 & $\mathrm{~kg}$ \\
\hline & \multirow{2}{*}{ Plant } & Concrete $^{\mathrm{a}}$ & 20.18 & $\mathrm{~kg}$ \\
\hline & & Reinforcing steel $^{\mathrm{a}}$ & 11.35 & $\mathrm{~kg}$ \\
\hline & \multirow{3}{*}{ Energy } & Electricity $^{\mathrm{c}}$ & 0.85 & $\mathrm{MWh}$ \\
\hline & & Cooling energy ${ }^{c}$ & 4.30 & $\mathrm{MWh}$ \\
\hline & & Process steam $^{\mathrm{c}}$ & 4.93 & $\mathrm{MWh}$ \\
\hline & Fuels & Propane $^{c}$ & 1.35 & $\mathrm{kWh}$ \\
\hline \multirow{4}{*}{ OUTPUT } & \multirow{4}{*}{ Products } & Bioethanol & 1000.00 & $\mathrm{~kg}$ \\
\hline & & biofuel solido & 1524.66 & $\mathrm{~kg}$ \\
\hline & & melassa & 1080.72 & $\mathrm{~kg}$ \\
\hline & & $\mathrm{CO}_{2}$ & 878.92 & $\mathrm{~kg}$ \\
\hline
\end{tabular}

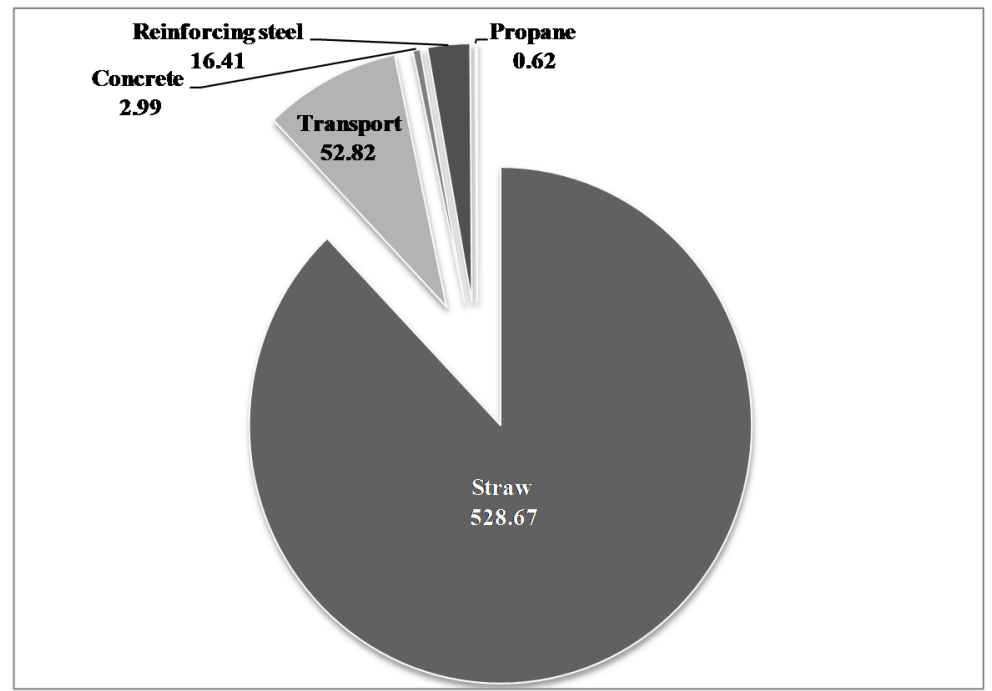

Figure 2: $\quad$ Total $\mathrm{CO}_{2}$ eq emissions for the production of 1 ton of bioethanol.

The $88 \%$ of the amount of $\mathrm{CO}_{2}$ eq released during the production process derives from straw production and collection. As reported in other LCA studies regarding biofuels [2], the agricultural phase requires the use of machineries, 
fertilizers and pesticides, implying high $\mathrm{CO}_{2}$ eq emissions. In the hypothesized system, this result is enhanced because we have assumed the use of residual geothermal heat as energy source that has zero GHG emissions [42]. Also the electricity used in the plant has been accounted with no GHG emissions as it is produced from geothermal power plant and it is already accounted in the GHG balance of the Province of Siena [21]. The transportation phase and the plant contribute for the $9 \%$ and $3 \%$ respectively to the total $\mathrm{CO}_{2}$ eq emissions of bioethanol production (Figure 2).

The substitution of bioethanol for gasoline results in an emission reduction of $13,259 \mathrm{tCO}_{2}$ eq, given by the avoided emission due to the replacement of gasoline $\left(13,773 \mathrm{tCO}_{2} \mathrm{eq}\right)$ minus the emission due to bioethanol production $\left(514 \mathrm{tCO}_{2} \mathrm{eq}\right)$. This result contributes to a decrease of $1 \%$ of the gross $\mathrm{CO}_{2}$ eq emissions of the Province of Siena. It must be noticed that the GHG emission of the agricultural phase (straw production) has not been attributed to the biofuel production chain because it is already included in the GHG inventory of the Province (this is a consequence of the use of a residual resource).

In particular, the $\mathrm{CO}_{2}$ eq related to the energy sector could decrease by $1.4 \%$, due to the fact that the emissions of the transport sector decrease by $2.2 \%$. Finally, in the overall balance (sequestration vs. emissions), the substitution of $10 \%$ of the gasoline could further decrease the percentage of net emissions that are already negative [21].

\section{Conclusions}

In this paper we have hypothesized to implement a bioethanol production chain to substitute the $10 \%$ of gasoline consumed within the Province of Siena. The emergy evaluation and LCA of the project have been performed, giving encouraging results under the environmental viewpoint. The project implies the use of residues from local productions: geothermal heat as energy source and straw as feedstock for the bioethanol production. We can maintain that this proposal falls within the framework of Herman Daly's quasi sustainability principle [43] on the use of non-renewable resources. In particular, we propose the use of non-renewable resources (such as steel, concrete, fuels - and their corresponding amount of $\mathrm{CO}_{2} \mathrm{eq}$ ) to increase the overall capacity of the system to capture and exploit a larger amount of renewable resources that are locally available [44]: in our case, straw and geothermal heat to produce bioethanol. In fact, the supposed straw utilization can represent an additional way to exploit residue from the crop production within the territory of the Province of Siena, without an increase in cropland or in areas intensively cultivated. This consideration is also valid for the residual geothermal heat that currently represents a valueless co-product of the electricity production process. The 2011 update differs from the calculations referred to 2008 [16, 17]. The main differences are due to the decreased amount of gasoline consumed in the Province of Siena in 2011 in respect to $2008(-14 \%)$ that results in a lower amount of bioethanol required, lower $\mathrm{CO}_{2}$ eq emissions and lower emergy investment $(17 \%)$. 


\section{References}

[1] Naik, S.N., Goud, V.V., Rout, P.K. \& Dalai, A.K., Production of first and second generation biofuels: A comprehensive review. Renewable and Sustainable. Renew. Sust. Energ. Rev., 14, pp. 578-597, 2010.

[2] Cherubini, F., Birda, N.D., Cowie, A., Jungmeier, G., Schlamadinger, B. \& Woess-Gallasch, S., Energy- and greenhouse gas-based LCA of biofuel and bioenergy systems: Key issues, ranges and recommendations. Resour. Conserv. Recycl. 53, pp. 434-447, 2009.

[3] Cherubini, F. \& Ulgiati, S., Crop residues as raw materials for biorefinery systems - A LCA case study. Appl. Energy, 87, pp. 47-57, 2010.

[4] Tan, K.T., Lee, K.T. \& Mohamed, A.R., Role of energy policy in renewable energy accomplishment: The case of second-generation bioethanol. Energ. Policy, 36, pp. 3360-3365, 2008.

[5] Huang, R., Su, R., Qi, W. \& He, Z., Bioconversion of Lignocellulose into Bioethanol: Process Intesification and Mechanism Research. Bioenerg. Res., 4, pp. 225-245, 2011.

[6] Wiloso, E.I., Heijungs, R. \& deSnoo, G.R., LCA of second generation bioethanol: A review and some issues to be resolved for good LCA practice. Renew. Sust. Energ. Rev., 16, pp. 5295-5308, 2011.

[7] Ghaley, B.B. \& Porter, J.R., Emergy synthesis of a combined food and energy production system compared to a conventional wheat (Triticum aestivum) production system. Ecol. Indic., 24, pp. 534-542, 2013.

[8] Tiezzi, E., Marchettini, N. \& Ulgiati, S., Integrated agro-industrial ecosystems: an assessment of the sustainability of a cogenerative approach to food, energy and chemicals production by photosynthesis. Ecological Economics: the science and management of sustainability. Ed. R. Costanza, R., ed. Columbia University Press: New York, USA, pp. 459-473. 1991.

[9] Coppola, F., Bastianoni, S. \& Østergard, H., Sustainability of bioethanol production from wheat with recycled residues as evaluated by Emergy assessment. Biomass Bioenergy, 33, pp. 1626-1642, 2009.

[10] Ghatak, H.R., Biorefineries from the perspective of sustainability: Feedstocks, products, and process. Renew. Sust. Energ. Rev., 15, pp. 40424052, 2011.

[11] International Energy Agency (IEA), 2008. Bioenergy Task 42 on Biorefineries: www.biorefinery.nllIEABioenergy-Task42.

[12] Lombardi, D.R., Lynos, D., Shi, H. \& Agarwal, A., Industrial Symbiosi. Testing the Boundaries and Advancing Knowledge. J. Ind. Ecol., 16(1), pp. 2-7, 2012.

[13] Gonela, V. \& Zhang, J., Design of the optimal industrial symbiosis system to improve bioethanol production. J. Clean Prod., 64, pp. 513-534, 2013.

[14] European Commission (EC), DIRECTIVE 2009/28/EC, 2009.

[15] European Commission (EC), DIRECTIVE 2009/30/EC, 2009.

[16] European Commission (EC), COM (2010) 2020. Communication From The Commission EUROPE 2020 - A strategy for smart, sustainable and inclusive growth, 2010. 
[17] European Commission (EC), COM (2011) 144. WHITE PAPER Roadmap to a Single European Transport Area - Towards a competitive and resource efficient transport system, 2011.

[18] Patrizi N., Pulselli F.M., Morandi F. \& Bastianoni S., Evaluation of the emergy investment needed for bioethanol production in a biorefinery using residual resources and energy. J. Clean Prod., in press.

[19] Patrizi, N., Caro, D., Pulselli, F.M., Bjerre, A.B. \& Bastianoni, S., Environmental feasibility of partial substitution of gasoline with ethanol in the Province of Siena (Italy). J. Clean Prod., 47, pp. 388-395, 2013.

[20] Singh, A., Pant, D., Korres N.E., Nizami A.S., Prasad, S. \& Murphy, J.D., Key issues in life cycle assessment of ethanol production from lignocellulosic biomass: challenges and perspectives. Bioresour. Technol., 101, pp. 5003-5012, 2010.

[21] Caro, D., Pulselli, F.M. \& Marchettini, N. The pathway of the Province of Siena toward the "Siena Carbon Free" goal. Sustainable City IX: Urban regeneration and sustainability. WIT Press, Southampton, UK, this volume.

[22] DONG. Integrated Biomass Utilization System. Final report, DK, 2006.

[23] Italian Department for Energy and Mineral Resources (D.G.E.R.M), Bulletin of Oil Sales, 2011.

[24] IPCC, IPCC Guideline for National Greenhouse Gas Inventories. Eggleston, H.S., Buendia, L., Miwa, K., Ngara, T., Tanabe, K., (Eds.), IGES, Japan, 2006.

[25] Thomsen, M.H., Thygesen, A. \& Thomsen, A.B., Hydrothermal treatment of wheat straw at pilot plant scale using a three-step reactor system aiming at high hemicellulose recovery, high cellulose digestibility and low lignin hydrolysis. Bioresour. Technol., 99, pp. 4221-4228, 2008.

[26] Agricultural Office of the Province of Siena, personal communication. 2011.

[27] ISTAT, 2011. Online: http://agri.istat.it/sag_is_pdwout/jsp/consultazione Dati.jsp.

[28] ARSIA, Sima della potenzialità produttiva delle agrienergie in Toscana, 2009.

[29] Børjesson, P. \& Tufvesson, L., Agricultural crop-based biofuels - resource efficiency and environmental performance including direct land use changes. J. Clean Prod., 19, pp. 108-120, 2011.

[30] Marland, G., West, T.O. \& Schalamadinger, B., Managing soil organic carbon in agriculture: the net effect on greenhouse gas emissions. Tellus, 55B, pp. 613-621, 2003.

[31] Odum, H.T., Emergy and biogeochemical cycles. In: C. Rossi, E. Tiezzi (Eds.), Ecological Physical Chemistry, Elsevier, Amsterdam, 1991.

[32] ISO 14040-14044, Environmental Management - Life Cycle Assessment Principles and Framework, Goal and scope definition and life cycle inventory analysis, Life cycle impact assessment and Life cycle interpretation - Life cycle assessment - Requirements and guidelines, 2006.

[33] Campbell, D.E, A revised solar transformity for tidal energy received by the earth and dissipated globally: implications for emergy analysis. Emergy 
Synthesis. Proceedings of the First Biennial Emergy Analysis Conference, ed. M.T. Brown, Center for Environmental Policy, University of Florida, Gainesville, pp. 255-264, 2000.

[34] Ulgiati, S., A comprehensive Energy and Economic Assessment of Biofuels: When "Green" is not Enough. Crit. Rev. Plant. Sci., 20(1), pp. 71-106, 2001.

[35] Jensen, K.H. \& Thyø, K.A., 2nd generation bioethanol for transport: the IBUS concept. Boundary conditions and environmental assessment. Master thesis Department of Manufacturing Engineering and Management Technical University of Denmark, 2007.

[36] Bastianoni, S., Campbell, D.E., Ridolfi, R. \& Pulselli, F.M., The solar transformity of petroleum fuels. Ecol. Model., 220, pp. 40-50, 2009.

[37] Cabezas, H., Campbell, D.E., Eason, T., Garmestani, A. S., Heberling, M.T., Hopton, M.E., Templeton, J., White, D. \& Zanowick, M., San Luis Basin Sustainability Metrics Project: A Methodology for Evaluating Regional Sustainability. Report number EP A/600/R-10/182 of the Office of Research and Development National Risk Management Research Laboratory, 2010.

[38] Campbell, D.E. \& Ohrt, A., Environmental Accounting Using Emergy: Evaluation of Minnesota. Report number AED-08-006 of the Atlantic Ecology Division (AED), National Health and Environmental Effects Research Laboratory (NHEERL), Office of Research and Development (ORD), USA, 2009.

[39] Pulselli, R.M., Simoncini, E., Ridolfi, R. \& Bastianoni, S., Specific emergy of cement and concrete: An energy-based appraisal of building materials and their transport. Ecol. Indic., 8, pp. 647-656, 2008.

[40] Pulselli, F.M., Patrizi, N. \& Focardi, S., Calculation of the unit emergy value of water in an Italian watershed. Ecol. Model., 222, pp. 2929-2938, 2011.

[41] Bastianoni, S., Marchettini, N., Principi, I. \& Tiezzi, E., Sviluppo di un modello di analisi emergetica per il sistema elettrico nazionale. Unpublished Report, Siena, Italy, 2001.

[42] Neupane, B., Halog, A. \& Dhungel, S., Attributional life cycle assessment of woodchips for bioethanol production. J. Clean Prod., 19(6-7), pp. 733$741,2011$.

[43] Daly, H.E., Toward some operational principles of sustainable development. Ecol. Econ., 2, pp. 1-6, 1990.

[44] Bastianoni, S., Pulselli, R.M. \& Pulselli F.M., Models of withdrawing renewable and non-renewable resources based on Odum's energy systems theory and Daly's quasi-sustainability principle. Ecol. Model., 220, pp. 1926-1930, 2009. 